\title{
Decentralisation and welfare reform in Andalusia
}

\section{Luis Moreno and Carlos Trelles *}

\begin{abstract}
Decentralization of the Spanish welfare state has stimulated regional policy innovation. A 'demonstration effect' among all Spanish Comunidades Autónomas has so far acted as a policy equalizer. In Andalusia, where a strong sense of common identity is widely shared, the regional government (Junta) has implemented new welfare policies which have contributed to consolidate its institutional legitimacy. This paper reviews the process of decentralization in Spain. It concentrates on the 'catching up' quest articulated by Andalusia to gain a similar status and degree of autonomy as those achieved by the 'historical nationalities' (Basque Country, Catalonia and Galicia).
\end{abstract}

Keywords:

Decentralization, financial autonomy, policy innovation, welfare

\section{Acknowledgements}

An earlier version of this paper was presented at the Seminar on Devolution and Public Policy, ECPR Standing Group on Regionalism, University of Edinburgh, October 2004. We thank Michael Keating and Nicola McEwen for helpful comments. We are also grateful to the Spanish Secretary of State for Education, Research and Universities (PR2002-0200 and SEC2002-01907) and the European Commission (Framework V, HPSE-CT2001-00078) for financial support.

\section{INTRODUCTION}

In contemporary EU member states, spatial cleavages and decentralization have often been examined as responses to regional claims for autonomy. Modernising strategies by sub-state layers of government have found in the principle of subsidiarity, enshrined in the Treaty on European Union, a renewed impulse for the running of public affairs, and new opportunities for policy experimentation. There is certainly a case for sub-state units to become laboratories of democracy'. It has been claimed that the payoff from innovation exceeds the advantages of uniformity and policy diffusion has been underlined as a criterion: the greater the need for innovation (for example, a 'new' problem or solution), the greater is the rationale for that function to be provided by the sub-state government (Donahue, 1997).

The political salience of sub-state regions and regional policy-making in the welfare realm has drawn growing attention to the inter-relationship of both fields of research: territory and welfare (McEwen and Moreno, 2005). Not so long ago, ideas, interests and institutions related to welfare and spatial developments were frequently regarded as contradictory or even incompatible with each other. Regional actors and mesogovernments have now gained relevance not only concerning culture and identity politics. They are increasingly regarded as optimal welfare policy providers as a result of the interaction of the processes of bottom-up globalization and the top-down devolution of powers.

\footnotetext{
* Unidad de Políticas Comparadas (UPC) Research Unit on Comparative Policy and Politics Spanish National Research Council (CSIC, Madrid) Email: Lmorfer@iesam.csic.es .
} 
The problem of territorial equity and cohesion has been mentioned frequently in discussions of the 'new regionalism' (Keating, 1998), but there has been little focus on the regional inputs of the welfare state. Of particular relevance are those policies concerned with welfare reform and the weaving of 'safety nets' to combat poverty and social exclusion. Such areas of social intervention appear suitable to be run by mesogovernments, which can be democratically accountable for the implementation of means-tested programmes, and for purposes of optimising economies of scale (Moreno, 2003).

This paper focusses on policies of welfare reform carried out by the Junta de Andalucía (Andalusian regional government). It singles out policy innovation implemented in Andalusia in line with the preference for a public provision of services. Likewise, we discuss the proactive, credit-claiming attitude of politicians and decision-makers in a poorer Spanish region as Andalusia, often regarded as backward and lacking the human capital and managerial skills necessary to promote policy initiatives.

We review, first, the process of decentralization in Spain and the role of the Comunidades Autónomas in social welfare since the inception of the 1978 Constitution. After identifying the ethnoterritorial mimesis, or 'demonstration effect', as a policy equalizer and an incentive for all Spanish Comunidades Autónomas not to be 'left behind', we concentrate on the 'catching up' quest articulated by Andalusia to gain a similar status and degree of autonomy as those achieved by the 'historical nationalities' (Basque Country, Catalonia and Galicia). We then carry out an analysis of the minimum income scheme designed, elaborated and implemented by the Junta de Andalucía, which illustrate the capabilities of this sub-state government for policy innovation in the welfare realm. A final section prior to the concluding remarks deals with financial matters and the aspirations of the Andalusia government for a higher degree of autonomy in expenditure decision-making.

The Kingdom of Spain is a constitutional monarchy of seventeen Comunidades Autónomas composed of: (a) three 'historical nationalities' (Basque Country, Catalonia and Galicia); (b) fourteen regions (Andalusia, Aragon, Asturias, Balearic Islands, Canary Islands, Cantabria, Castille-La Mancha, Castille and Leon, Extremadura, La Rioja, Madrid, Murcia, Navarre and Valencia); and (c) two Spanish North-African autonomous cities (Ceuta and Melilla) (see Table 1 for basic regional data).

The Spanish 1978 Constitution does not include the word 'federal' in any of its provisions, or in any subsequent legislation. However, since the beginning of the 1980s the dynamics of the Estado de las Autonomías ('State of Autonomies') are characterized by a latent federalization (Moreno, 2001). After 25 years since the beginning of the decentralization of powers, the Spanish 'State of Autonomies' (Estado de las Autonomías) has achieved a high degree of popular support largely transcending past patterns of internal confrontation (CIS, 1998, 2002).

In Spain, social assistance is a regional power of 'exclusive competence' of the Comunidades Autónomas (art. 148; 1.20; 1978 Constitution). Powers concerning the basic legislation and the economic regime of the national Social Security system remain within the domain of the central administration. However, the Comunidades Autónomas may have executive autonomy over the running and managing of contributory programmes (art. 149; 1.17). As a consequence of the flexibility of the constitutional provisions, all Comunidades Autónomas 3 claimed in their Statutes of Autonomy (regional constitutional laws) a large number of services and functions 
concerning social assistance, social services, community development, social promotion and welfare policies in general. ${ }^{1}$

During 1982-1993, the Comunidades Autónomas took the legislative initiative in their regional parliaments, and passed acts establishing regional systems of social services. The main concern for the Spanish mesogovernments was to request and receive as many powers from the central administration as they could be entitled to. They subsequently made extensive use of their constitutional prerogative for the purposes of institutional legitimization (Arriba and Moreno, 2005).

An important agreement for social policy provision between the three layers of government took place in 1987 with the approval of the 'Concerted Plan for the Development of the Basic Provision of Social Services by the Local Authorities' (Plan Concertado para el Desarrollo de Prestaciones Básicas de Servicios Sociales de las Corporaciones Locales). This intergovernmental agreement has resulted in administrative co-operation between central, regional and local governments. The aim is to provide services at the municipal level for a variety of purposes, including: (a) information and counselling; (b) social and day care services for the disabled and elderly; (c) refuge for abused women, single mothers, orphans or mistreated minors, and shelter housing for the homeless; and (d) prevention and social insertion. This network of centres constitutes the basic level for welfare primary attention in Spain and was supported by all Autonomous Communities except the Basque Country. ${ }^{2}$ Annual financing of this Plan is met on equitable terms by the three layers of governments. This agreement was the first in a model of intergovernmental relations characteristic of the process of federalization in Spain. Its implications for other policy areas have been of no little significance.

In the period 1994-2004, the Comunidades Autónomas that had previously received the higher number of competences (Andalusia, Basque Country, Canary Islands, Catalonia, Galicia, Navarre and Valencia) carried out extensive policy-making in the welfare realm. On identifying the patterns followed by those Communities when allocating responsibilities for welfare to the stakeholders in the different social domains (public, private, family and social network domains), a contrasting policy configuration has emerged. Andalusia, the object of our analysis, has made choices in social policy-making most influenced by the public sector and the family. Regional public institutions have played an important role in the development of social policy in Andalusia, but this is combined with a pivotal role played by the family in welfare provision and distribution, a feature characteristic of the Southern European welfare regime (Gallego et al., 2005).

In general policy terms, the process of decentralization has allowed for considerable regional autonomy. If public spending is to be identified as a good indicator of the level of regional autonomy (Watts, 2001), then it should be concluded that the Spanish Comunidades Autónomas enjoy a much higher degree of self-government as compared to federated units in formally established federations in the world. Likewise, the extent of decentralized powers in

\footnotetext{
${ }^{1}$ The only social services which remained outside the jurisdiction of the mesogovernments were those of the National Institute of Social Services (INSERSO). However, during the 1990s the executive powers for the running of practically all INSERSO social services were also transferred to the Comunidades Autónomas.

${ }^{2}$ On the basis of their historical rights, the Comunidades Autónomas of the Basque Country and Navarre have a distinctive fiscal regime which enables them to collect their own taxes. Subsequently, they transfer a previously agreed quota to the central state Treasury as compensation for Spanish common expenditure, and to cover the costs of running those state administrative bodies located in the Basque Country and Navarre. As the Basque Country government did not want to accept categorical grants, which indicated how the money should be spent, it remained outside the Concerted Plan. The Navarran government join the Plan although in a testimonial manner.
} 
Spain is illustrated by the percentages of public employees under the responsibility of each level of government: 25 per cent (central), 53 per cent (regional), and 22 per cent (local), with the balance shifting from central to regional administrations in recent years. ${ }^{3}$ The decentralization of welfare competences in Spain has stimulated policy innovation, with a 'race to the top' that so far has minimized the alleged detrimental consequences for state national solidarity. As a result of the fragmented nature of the system of social protection in Spain, and the deep process of decentralization of welfare competencies, the central layer of government can be regarded as one playing a subsidiary role with respect to the regions in matters of social welfare (Arriba and Moreno, 2005).

In political terms, the gradual establishment of the Estado de las Autonomías in Spain has generated a complex set of relations which can be explained as multiple ethnoterritorial concurrence (Moreno, 1995; Lecours, 2004). The rule of the ethnoterritorial mimesis, or the practices of policy equalization among the Comunidades Autónomas by means of imitation, has been the main factor responsible for 'tuning' the decentralization process in Spain. After the approval of their Statutes of Autonomy (regional constitutional laws), the 'historical nationalities' (the Basque Country, Catalonia and Galicia) aimed at replicating the powers and symbols of the Spanish central state (for example, establishing a separate police force, developing paradiplomacy activities and overarching public policies in nation-building fields such as those of education, health or media, and promoting external and ornamental signs such as the flag, the anthem). On deploying their political claims during the 1980 s, a second group of Comunidades Autónomas with 'catching up' aspirations for home rule (Andalusia, Canary Islands, Navarre, and Valencia) ${ }^{4}$ struggled not to feel discriminated against by the achievements of those 'early rising' regions referred to in the second stage of the mimetic sequence. Regional ethnoterritorial mimesis and the practices of the 'demonstration effect' extended all over Spain including those communities with less well-defined ethnoterritorial identities.

\section{ANDALUSIA, A DISTINCTIVE QUEST FOR HOME RULE}

In the general process of Spain's decentralization during the 1980s, the case of Andalusia is of particular relevance. Andalusian leaders and the population at large mobilised in order to achieve the same 'fast route' procedure and degree of home rule previously pursued by the three 'historical nationalities'. According to the constitutional provisions, and in order to achieve a faster and deeper access to regional autonomy equal to that of the Basque Country, Catalonia and Galicia, a popular referendum was held on 28 February 1980 in Andalusia. ${ }^{5}$

The outcome of the referendum ratified Andalusian popular aspirations for full regional autonomy. Moreover, it led the way for other regions in their pursuit for access to home rule. This development brought about a crucial element of heterogeneity that contested the idea of

\footnotetext{
${ }^{3}$ In 1999, the corresponding percentages were 41\%, 34\% and 25\%, respectively (El Mundo, 16 August 2004). ${ }^{4}$ Already in 1984, Joan Lerma (President of the Valencian Government) considered that there were not three 'historical nationalities', but six Comunidades Autónomas with different levels of powers: '... they are allowed to get to the same place, and in particular I have to emphasise that the legal treatment for Catalonia and the Basque Country is the same as that for Galicia, but also for Andalusia, the Canaries and for ourselves [the Valencians]' (La Vanguardia, 16 April 1984).

${ }^{5}$ The referendum was held after $97 \%$ of Andalusian towns and eight provincial councils had decided to pursue autonomy according to the provisions of art. 151 of the 1978 Constitution. The $64 \%$ turnout rate was considered high. However, the rules stipulated that a 'yes' vote required the endorsement of more than $50 \%$ of the registered votes in each of the eight Andalusian provinces. The results were somewhat controversial because, despite the considerable support for autonomy in Andalusia as a whole, in the province of Almería, only $47 \%$ of the inhabitants voted 'yes'. Finally, the political situation that had arisen made it impossible to turn back on the 'fast route' of art. 151.
} 
considering asymmetry in the Spanish devolutionary process as a function of sub-state nationalism (Beramendi and Máiz, 2004). This view had been implicitly defended by some Catalan and Basque nationalists: i.e. implementing political decentralization only in the Spanish 'historical nationalities' while the rest of the regions would merely be granted administrative decentralization. Since then, nationalist parties in the three 'historical nationalities' have tried to establish a 'political differential' with respect to the rest of the Comunidades Autónomas, which they regard as mere 'regions'. In turn, political formations in the regions have rejected the idea of granting privileges to the 'historical nationalities' and have resisted pressure to conform to a lower level of political autonomy.

Certainly, the nationalist PSA/PA (Partido Socialista de Andalucía/Partido Andalucista) and the Andalusian Communists and Radical Leftists (Partido Comunista de Andalucía/Izquierda Unida Los Verdes-Convocatoria por Andalucía) have had considerable political input in claiming a higher degree of self-government, but the role played by the Andalusian Federation of the PSOE can be singled out as crucial in the development of the home rule process. The case of Andalusia shows how a hegemonic non-nationalist party with a strong regionalist agenda can press effectively for political autonomy at sub-state level, while maintaining its channels of influence at the core of the national political system.

On claiming higher degrees of self-government, identity politics constitute a powerful instrument for political mobilization in all Spanish Comunidades Autónomas. In Andalusia there is a strong sense of collective identity. A mutual sense of belonging is shared by a large majority of the population based upon a secular and powerful culture. The intense mobilization prior to the 1980 referendum was the expression not only of a re-assertion of regional pride, but also of a refusal to be considered 'less' than Basques, Catalans or Galicians. As evident in Table 3, Andalusians' strong sub-state identity and culture coincides. he referendum was held after $97 \%$ of Andalusian towns and eight provincial councils had decided to pursue autonomy according to the provisions of art. 151 of the 1978 Constitution. The $64 \%$ turnout rate was considered high. However, the rules stipulated that a 'yes' vote required the endorsement of more than $50 \%$ of the registered votes in each of the eight Andalusian provinces. The results were somewhat controversial because, despite the considerable support for autonomy in Andalusia as a whole, in the province of Almería, only $47 \%$ of the inhabitants voted 'yes'. Finally, the political situation that had arisen made it impossible to turn back on the 'fast route' of art. 151. 6 with a strong sense of being Spanish. This level of 'dual identity', reflected in the way in which citizens identify themselves, indicates that Andalusians share their institutional loyalties at both levels of political legitimacy (national and regional) without any apparent fracture between them.

Elements of common ancestry and way of life combine with those of comparative grievances in a Comunidad Autónoma traditionally in an economic backward position with respect to other Spanish territories. Accordingly, the desire for home rule also combines with the belief that the central state must secure inter-regional solidarity and policies to promote economic development in Andalusia. The Spanish Socialist Party (PSOE) has been the party which has managed both of these political discourses. Andalusia is an electoral stronghold for socialdemocratic PSOE. Since the first regional elections held in 1982, the PSOE has been the most popular party in Andalusia and has consistently controlled the Junta (see Table 4 for the evolution of the electoral results).

The influence of Andalusia in national politics, and in particular within the PSOE, is large if only for demographic reasons (it is the most populated region in Spain, with more than 7.6 million inhabitants, and has the largest rank-and-file membership of the Socialist Party). The PSOE has been able to win all Andalusian regional elections, including those held during the hegemonic 
period of the conservative Popular Party (PP) in national politics (1996-2004). Under the political control of the PSOE, the Junta contested several decisions and policies taken by the PP national government. It did so claiming to preserve not only their own autonomy, but also with the aim of ideologically challenging central government on matters of policy options and political ideas. Indeed, the diverse political colouring of both regional and central governments has been a latent motive of confrontation, which sometimes reached the level of bitter disagreements. The case of the 'pending balance' (deuda histórica) due to the Junta by the central treasury, briefly analysed further below, is illustrative in this respect.

In 1989 it was a member of the Group of the European Liberal Democrats and Reform Party (ELDR) in the European Parliament. PCA-IULV: Andalusian Communist Party affiliated to the PCE (Spanish Communist Party) and IULV-CA (Left coalition of PCE, greens, radical socialists and independent leftists). Member of the Confederal Group of the European United Left Nordic Green Left in the European Parliament. PSA-PA: Andalusian Socialist Party (PSA) later transformed into centre-left nationalist Andalusian Party (PA). During the period 1999-2004, the representative of the PA in the European Parliament joined the Greens/European Free Alliance Group. In 2004, the PA obtained no seat in the European Parliament. Source: Own elaboration on data from the Centre of Analysis and Political and Electoral Documentation in Andalusia (CADPEA) (cadpea.ugr.es/web/default.aspx).

The Andalusian federation of the PSOE embraces federalism, which is the 'official' line of the Socialist Party, but which is not always shared with the same degree of conviction by other branch organizations. By controlling a large Spanish Comunidad Autónoma, the Socialists have been able to pursue their autonomist philosophy without alienating either 'centralist' or 'peripheral' views within the party. Since 1982 the Junta have been able to implement public programmes which have enjoyed steady popular support, manifested in the electoral successes of the Socialists in all three local, regional and national elections in Andalusia.

\section{WELFARE REFORM IN A POORER REGION}

The Junta has reinforced its 'catching up' attitude in the development of new public policies. The traditional neglect of private entrepreneurship in establishing new growth poles in Andalusia has had its counterpoint in an active involvement of the Andalusian 8 mesogovernment in attempting to weave a welfare 'safety net' in a less prosperous region (Fundación La Caixa, 2004).

The Andalusian Statute of Autonomy in its Preliminary Title (art. 12) set the goals to promote and to achieve greater welfare levels of the population, to achieve effective gender equality, and to support resource equity among social groups. According to art. 13.22 of the Andalusian Statute of Autonomy: 'The Comunidad Autónoma of Andalusia has exclusive competence in assistance and social services matters [and] family planning and counselling'. Further to their powers in this area, the Junta later assumed the management and organization of social services, many of which are within the Spanish Social Security system.

In attempting to develop an integral notion of social welfare, the Andalusian Statute gives priority to the social protection of the family. It contemplates the possibility of regulating matters like the protection of minors (art. 13.23) and the promotion of activities and services for youth and the elderly. It also makes a general reference to community development (art. 13.30). All these objectives are to be pursued by carrying out 'long-term' social policy programmes. 
Law 2/1988 on Andalusian Social Services aimed at optimising the organization of the services and programmes by unifying dispersed units and eliminating duplicated structures. The process of organization and unification of the public system of social services was finally completed with the establishment of the Secretaryship of Social Affairs (Consejería de Asuntos Sociales) in 1990. Since then this Secretaryship has kept its modified denomination as Secretaryship for Equality and Social Welfare (Consejería para la Igualdad y Bienestar Social).

Since 1988, a sustained growth in welfare spending has been noticeable (Figure 1). Those increases in social expenditure are congruent with an approach for policy innovation and development of public welfare programmes carried out by the Junta. However, such an experimental and incremental exercise has not been developed in vacuum. In many cases new programmes have been the result of a process of policy learning by which the Junta has made its own 'adaptation' of programmes already implemented in other Comunidades Autónomas. These have generally kept an eye on each other, and have scrutinized, both formally and informally, the running of devolved services and those implemented ex novo.

In the section below, we briefly analyse a new policy, the minimum income scheme. This will serve to illustrate the political priorities and functional capabilities of the Junta regarding social welfare, although a more detailed and long-term examination of the vicissitudes of the programme would be needed in order to assess the extent of its innovative effects.

\section{The Andalusian Minimum Income Scheme (Programa de Solidaridad de los Andaluces)}

In 1988, the Spanish central government initiated a period of expansion in welfare spending in the non-contributory area. The Social Security system met the costs of the two main policies implemented at the time: (a) a generalization of the right to a retirement pension, and (b) a disability allowance for people of limited resources and insufficient contributing funds. In parallel, regional governments began to develop the programmes of public schemes for minimum income guaranteed, known as rentas mínimas de inserción. Local governments were in charge of their management. These schemes were designed to facilitate social insertion of the poorest and marginal sectors of the population and were implemented in almost all the Comunidades Autónomas in a concatenated process between 1988 and 1992. The Basque Country was the first to take the initiative, sparking a regional mimesis or 'demonstration effect' on the part of the other sixteen Comunidades Autónomas (Arriba, 2001).

The Programme of Solidarity for Andalusians (Programa de Solidaridad de los Andaluces) was negotiated by the Junta with the main trade unions prior the promulgation of the Decree $400 / 1990$ (November), later replaced by Decree 2/1999. Since then, the programme has operated as a complementary policy of social protection in both the contributory and assistance levels. Its 'workfare' philosophy is geared towards achieving social insertion for needy Andalusian citizens and avoiding a purely assistance character.

The various regional programmes of minimum income have been implemented with roughly the same features (combining cash benefits with activities of social insertion). They also established common requirements, such as: (a) to have a family as a unit of reference; ${ }^{6}$ (b) means-tested criteria related to a threshold of household income under which cash benefits

\footnotetext{
${ }^{6}$ Although one person can form a 'familiar unit' when is over 25 years of age and lives in a solo household. In the case of Andalusia, family units can have access to minimum income scheme if they have been formed in a 'stable form' at least one year before the request, except for some exceptional cases, and all family members are registered in an Andalusian municipality, at least for one year.
} 
are awarded; (c) to have a residence status for applicants; and, (d) periods of extension are available when the beneficiaries have complied with social insertion activities.

Andalusia has not only implemented social services to facilitate access to the system of social protection. It has also introduced procedures for promoting social insertion outside the framework of social services. Andalusia, Catalonia, Valencia and Madrid started their programmes of minimum income one year later than the Basque Country, and they all shared the common principle of its interdepartmental management. This approach was in itself an innovation and facilitated the common involvement of several regional bodies in offering an integral solution to the problem of poverty and exclusion. Andalusia established a set of measures in the field of education, occupational training, employment and housing, with the Although one person can form a 'familiar unit' when is over 25 years of age and lives in a solo household. In the case of Andalusia, family units can have access to minimum income scheme if they have been formed in a 'stable form' at least one year before the request, except for some exceptional cases, and all family members are registered in an Andalusian municipality, at least for one year. 10 planning and participation of different regional public bodies (Aguilar, Gaviria and Laparra, 1995).

Together with the payment of the minimum income benefit (see Table 5), the beneficiary may receive occupational training and other programmes monitored by the Secretaryship of Labour and Industry (Consejería de Trabajo e Industria). Educational measures for which the Secretaryship of Education and Science (Consejería de Educación y Ciencia) is responsible include programmes for adult education. A housing subsidy for beneficiaries can reach up to 90 per cent of the house rental, and monetary support may be awarded for house rehabilitation. Achievement of this activity is made possible by the Plan for Neighbourhood Preferential Intervention (Plan de Barriadas de Actuación Preferente), aimed at investing in urban spaces with serious problems of poverty and deprivation, difficulties in matters of urban damages, deterioration of infrastructure, and significant hygienic and sanitary deficiencies. However, both occupational training and educational measures have played the main role within the Programa de Solidaridad de los Andaluces.

The Programme has had a strong workfare philosophy functioning as a mechanism of economic aid by means of temporary jobs directed at the excluded urban population, who were not entitled to benefits such as those of the Programme for Rural Employment (Plan de Empleo Rural, PER) and the Agrarian Subsidy. Therefore, it has provided more protection to needy Andalusians while increasing their opportunities for labour insertion. Temporary jobs have usually been subsidized and made available by local authorities on a full-time basis and with a six-month duration (Cornejo, 2001).

The final awarding of these benefits is dependent on the signing by the beneficiaries of the Commitment of Insertion (Compromiso de Inserción). ${ }^{7}$ The adult members of the family unit must comply with a number of responsibilities concerning the internal life of the household 7 The regional offices responsible for the fulfilment of the Commitment of Insertion are the Provincial Delegations of the Secretaryship of Equality and Social Welfare (Delegaciones Provinciales de la Consejería para la Igualdad y Bienestar Social), and the municipalities where the beneficiaries reside.

\footnotetext{
7 The regional offices responsible for the fulfilment of the Commitment of Insertion are the Provincial Delegations of the Secretaryship of Equality and Social Welfare (Delegaciones Provinciales de la Consejería para la Igualdad y Bienestar Social), and the municipalities where the beneficiaries reside.
} 
The Programme of Solidarity (Programa de Solidaridad) can be regarded as rather modest in dealing with poverty and social exclusion in Andalusia. However, the importance of this programme is crucial for the maintenance of a welfare 'safety net' as it is the 'last resort' public subsidy to which both the poor and the excluded can have access in Andalusia (Arriba, 2001). Criticisms have been expressed that this type of programmes elaborated and implemented under the full responsibility of the Comunidades Autónomas may increase regional differences in social spending. An important explanation for policy divergence among the various regional minimum income schemes in Spain can be found in the variable financial manoeuvrability of the Comunidades Autónomas. The Basque Country and Navarre, richer than others, have a system of fiscal quasi-independence which has allowed them to generously fund their programmes of rentas mínimas. Despite their economic disadvantage, poorer regions have nevertheless been able to design their own areas of intervention for accomplishing social insertion.

\section{FINANCIAL AUTONOMY AND SPENDING CHOICES}

As already stated, policy options and initiatives have been conditioned by the economic situation of the second poorest region in Spain, according to per head regional GDP figures (see Table 1). In many instances, Andalusia has not reached the desirable minimum level of public service provision as proclaimed by the 1978 Constitution for the whole of Spain. ${ }^{8}$ The 8 According to art. 158, central state budgets must guarantee a common level of basic public services throughout the Spanish territory. The episode of the $€ 2.5$ billion 'pending balance' (deuda histórica) is illustrative of the difficulties of articulating a stable financial settlement for all the Comunidades Autónomas. ${ }^{9}$

As a consequence of a mismatch in the calculation of the moneys to be transferred to the Junta by the central treasury according to a previous system of financing, the sum of $€ 2.5$ billion was in arrears. Both national and regional governments contested the figures although the reasons were more 'political' than 'technical'. The issue became a motive of confrontation between PP and PSOE on approaching both Andalusian and Spanish elections (which were held simultaneously on 15 March 2004). The Minister of Economy of the PP central government stated that the case of the pending payment would be resolved if the PP were to win the Andalusian election. Not long after the landslide victory of the PSOE and the heavy electoral losses of the PP, the Junta and the central Treasury, whose representatives were members of the same Socialist Party, reached an agreement: the pending $€ 2,500$ million was settled.

Funding for the Andalusian Junta is composed mainly of: (a) shares of the national revenue collected by major taxes (since 2002 regional percentages correspond to 33 per cent of income tax, 35 per cent of VAT and 40 per cent of special taxes on petrol, tobacco and spirits); ${ }^{10}$ (b) sums accrued by the concession and management of certain taxes (judicial acts and municipal taxes, luxury and heritage taxes, inheritance tax and transfers, or gambling taxes); (c) moneys

\footnotetext{
${ }^{8}$ According to art. 158, central state budgets must guarantee a common level of basic public services throughout the Spanish territory.

${ }^{9}$ The claim by the Junta for the 'deuda histórica' was grounded in the provision of the 1982 Statute of Autonomy recognizing the incapability of Andalusia - due to their socio-economic limitations - to provide a minimum level of public services similar to that of the rest of Spain. Equalization amounts were transferred by the central treasury (Fondos de Cohesión) to repay the extra financial effort made by the Junta in its anual budgets since the 1980s. The question remains rather 'open' as resources needed for Andalusia to reach a similar level of public service provision to the optimal Spanish mean must take into account not only initial investments but future running costs for the maintenance of the programmes.

10 This 'basket' of taxes was strongly supported by the Junta and achieved a complete consensus between the central government and the 15 Comunidades Autónomas of the 'common regime' at the sectoral conference of the Council of Financial and Fiscal Policies (Consejo de Política Fiscal y Financiera).
} 
from the European funds; and (d) public debt. The funds transferred from the central treasury are not categorical or 'earmarked' for any service provision. The Comunidades Autónomas have freedom of choice about which services and policies under their jurisdiction are to be better funded. However, problems of under-budgeting and overspending (or estimating fewer amounts in the annual budgets than actual costs) are still a matter of political contention and are becoming increasingly contested.

The task of assessing the financial consequences of 'chronic' under-budgeting and overspending by nationalities and regions is by no means easy. Too often the effects of public borrowing are not 'evident' at short-term. Only longitudinal studies on extended time series can assess the impacts of budget mismatching concerning the survival or modification of policies. Since the beginning of the process of decentralization, nationalities and regions have made use of their constitutional prerogative to obtain 'extra' funds by issuing regional public debt to finance policies and services. In some cases these fresh moneys have made possible the financing of new programmes. In others, extra financing has been applied to compensate for shortcomings in the funding of decentralized services, which eventually became more costly to run because of unforeseen reasons (for example, the impact of immigration in health provision expenses). ${ }^{11}$

In some instances the Comunidades Autónomas have attempted to display 'blame avoidance' practices and to divert their own responsibilities by portraying the central state as a 'scapegoat' of their own failures; in other circumstances, central administration officials have referred (usually 'off-the-record') to the insufficient skills of regional policy-makers. In such a process of mutual indictments, popular 'understanding' has generally sympathized with the regional claims, while central managers have usually struggled with the reputation of being inheritors of a centralist mentality characteristic of the former dictatorship (Solé Tura, 1985; Moreno, 2004).

Not surprisingly, the priority that the Junta has placed in reforming the Statute of Autonomy relates to the achievement of the so-called 'Andalusian fiscal space' (espacio fiscal propio). ${ }^{12}$ This request implies normative powers and full capacity for the management of tax collection with the establishment of the Tax Agency of Andalusia (Agencia Tributaria de Andalucía). The agency would be in charge of fiscal matters and would make more visible the 'co-

responsibility' of Andalusian authorities in optimising resources of control, not only to combat fraud, but also to promote transparency and popular legitimacy for regional policies.

Although in a loose manner, this option of finance settlement would be one of 'tributary confederation' along the lines of those enjoyed by Navarre and the Basque Country. That is to say, the Comunidades Autónomas would collect most of the taxes and would then pay the state previously agreed sums or quotas for the general state budget. This possibility appears desirable insofar as it would be clearer for the citizens to assess expenditure responsibilities by mesogovernments of the Comunidades Autónomas. However, it would also require greater

\footnotetext{
11 The claim by the Junta for the 'deuda histórica' was grounded in the provision of the 1982 Statute of Autonomy recognizing the incapability of Andalusia - due to their socio-economic limitations - to provide a minimum level of public services similar to that of the rest of Spain. Equalization amounts were transferred by the central treasury (Fondos de Cohesión) to repay the extra financial effort made by the Junta in its annual budgets since the 1980s. The question remains rather 'open' as resources needed for Andalusia to reach a similar level of public service provision to the optimal Spanish mean must take into account not only initial investments but future running costs for the maintenance of the programmes.

12 Manuel Chaves, President of the Junta, has proposed a debate in the Andalusian Parliament which could also deal with the issue of the 'horizontal' participation of Andalusia in the state-wide decision making, the writing of a bill of social rights and the territorial planning of the Comunidad Autónoma.
} 
specification where the principle of solidarity is concerned, in the form of explicit transfer requirements between rich and poor communities (Moreno, 2001).

In line with a pro-active approach to policy-making based upon a 'catching up' stance, the Junta aims at achieving the 'maximum degree of financial autonomy' (Presidencia de la Junta, $2003 ; 9 / 4)$. As happened in the past, the Junta is not prepared to accept any asymmetrical arrangement with other Comunidades Autónomas which could be seen as a 'privilege'. Furthermore, the emphasis is put by the Junta on the use of updated and 'real' population as the main criterion to be taken into account for the calculation of the sharing of state revenue. Andalusia is the most populated Comunidad Autónoma with $17.8 \%$ of the Spanish total (see Table 1).

\section{CONCLUDING REMARKS}

During the last 25 years, Spain has undergone a widespread process of political decentralization and home-rule-all-round. The level of self-government reached by the Spanish Comunidades Autónomas is high as compared with most of the decentralized countries in the world. At the beginning of the process of devolution, the quest of Andalusia to achieve a similar degree and level of self-government as the 'historical nationalities' brought about a further stimulus to self-government in the rest of the Spanish regions. Such a development set in motion a general process of mimesis by other Comunidades Autónomas, which entered a 'race to the top' with each other in order to gain as many decentralized powers as possible. Generalitat was expected to collect $€ 60$ million in 2004 , just $10 \%$ of the forecast deficit (El País, 13 September 2004).

In the welfare field of public provision, the Andalusian Junta has implemented a number of new policies which have contributed to consolidate its institutional legitimacy and to reinforce a strong regionalist political agenda. In parallel, this Comunidad Autónoma, where a strong sense of common identity and a mutual sense of belonging are widely shared, has also continued to count on the 'umbrella' of non-discriminatory provisions guaranteed by the Spanish 1978 Constitution.

Financial settlement for the funding of new policies by the Junta continues to be a matter of dispute. Of crucial importance for the financing of new welfare programmes is the establishment of what the Junta has labelled its 'own fiscal space' (espacio fiscal propio). This would guarantee a percentage share of the major national taxes which would form a 'basket' providing a stable and reliable fiscal autonomy to Andalusia. The limit to such fiscal powers would be reflected in the maintenance of the social security system on a nation-wide basis.

Decentralization of the Spanish welfare state has stimulated regional policy innovation, with a 'demonstration effect' that, so far, has minimised the detrimental consequences for state national solidarity. Assessment of policy outcomes, as those innovative programmes carried out by the Junta, should also be considered and scrutinized over longer time periods. Such an analytical exercise is crucial to evaluating not only the compliance of policy goals, but also levels of legitimacy and popular support for regional autonomy.

\section{REFERENCES}

Aguilar, Manuel; Gaviria, Mario and Laparra, Miguel (1995), La Caña y el Pez. El salario social en las Comunidades Autónomas 1989-1994. Madrid: Fundación Foessa. 
Arriba, Ana (2001), 'Procesos de Implantación de Políticas de Rentas Mínimas de Inserción de España', in Luis Moreno (ed.), Pobreza y Exclusión: La 'malla de seguridad' en España. Madrid: CSIC.

Arriba, Ana and Moreno, Luis (2005), 'Spain: Poverty, social exclusion and safety nets', in Maurizio Ferrera (ed.), Welfare Reform in Southern Europe, London: Routledge.

Beramendi, Pablo and Máiz, Ramón (2004), 'Spain. Unfulfilled Federalism (1978-1996)', in Ugo M. Amoretti and Nancy Bermeo (eds.), Federalism and Territorial Cleavages. Baltimore: The Johns Hopkins University Press. CIS (1998), Estudio 2.286. Madrid: Centro de Investigaciones Sociológicas. CIS (2002), Estudio 2.455. Madrid: Centro de Investigaciones Sociológicas.

Cornejo, Juan (2001), 'Las rentas mínimas de inserción en Andalucía (1990/2001): El Programa de Solidaridad de los Andaluces', in Luis Moreno (ed.), Pobreza y Exclusión: La 'malla de seguridad' en España. Madrid: CSIC

Donahue, John (1997) Disunited States, New York: Basic Books. Fundación La Caixa (2004), Anuario Social de España 2004, Barcelona: Servicio de Estudios de La Caixa.

Gallego, Raquel; Gomà, Ricard and Subirats, Joan (2005), 'Spain, From State Welfare to Regional Welfare?', in Nicola McEwen and Luis Moreno (eds.), The Territorial Politics of Welfare. London: Routledge.

IEA (2001), Anuario Estadístico de Andalucía. Seville: Instituto de Estadística de Andalucía. Keating, Michael (1998) The New Regionalism in Western Europe. Territorial Restructuring and Political Change, Cheltenham: Edward Elgar.

Lecours, Andre (2004), 'Moreno's Multiple Ethnoterritorial Concurrence Model: A Reformulation', Regional and Federal Studies, Vol.14, No.1, pp.66-88. MAP (1997), Estudio sobre reparto del gasto público en 1997 entre los distintos niveles de administración. Madrid:

Ministerio de Administraciones Públicas. MAP (2002), Estimación del reparto del gasto público entre los subsectores de administraciones públicas (1982-2002). Madrid: Ministerio de Administraciones Públicas.

Moreno, Luis (1995), 'Multiple Ethnoterritorial Concurrence', Nationalism and Ethnic Politics, Vol.1, No.1, pp.11- 32.

Moreno, Luis (2001) The Federalization of Spain, London: Frank Cass. Moreno, Luis (2003) 'Europeanization, mesogovernments and safety nets', European Journal of Political Research, Vol.42, No.2, pp.185-199.

Moreno, Luis (2004), 'Divided societies: Electoral polarization and the Basque country', in Adrian Guelke (ed.), Democracy and Ethnic Conflict. Basingstoke: Palgrave Macmillan.

McEwen, Nicola and Moreno, Luis (eds.) (2005), The Territorial Politics of Welfare. London: Routledge. Presidencia de la Junta (2003), Bases para la Reforma del Estatuto de Autonomía de Andalucía. Seville: Junta de Andalucía (16 December, 2003).

Solé Tura, Jordi (1985), Nacionalidades y nacionalismos en España. Autonomías, federalismo, autodeterminación. Madrid: Alianza. Watts, Ronald (2001), 'Models of federal power-sharing', International Social Science Journal, Vol.53, No.167, pp.23-32. 